\title{
The Relationship between Quality of Work Life and Customer Relationship Management (CRM) in State Banks of Maragheh City
}

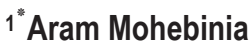 \\ ${ }^{2}$ Yahya Dadashkarimi
}

1,2Depart of Management, Bonab Branch, Islamic Azad University, Bonab, Iran

\author{
Doi:10.5901/mjss.2016.v7n5s1p174
}

\begin{abstract}
High-quality working environment is known as a basic prerequisite of empowering human resources required organizational system. Understanding the quality of their working as employees of an organization of the working group, in terms of its importance in the operation have been considered. On the other hand productivity in employees' personnel will be a major factor in the success of the organization. If the correlation between quality of work life and the relationship with the customer and ultimately productivity be clear, managers can improve the quality of workplace productivity by providing staff. The population consisted of managers of state banks constitute the province that consists of 100 employees. The sampling method based on random sampling of the population is mentioned. Therefore, this study is performed to investigate the relationship between these two variables together. The overall result is that the quality of work life better, as well as customer relationship management in state banks to be studied further.
\end{abstract}

Keywords: quality of work life, customer relationship management, state banks.

\section{Introduction}

One of the important issues in human resources, which has attracted the attention of researchers and writers, is the quality of work life (Andrade, 2003). According to Walton (1973), in recent years the quality of work life programs has played an important role in increasing labor productivity and as a result, the efficiency and effectiveness of large organizations. Quality of work life is a comprehensive program designed to achieve staff satisfaction, helping them to manage change and retention of staff (Knox et al., 2003). Dissatisfaction with the quality of work life is a fundamental problem that regardless of position affects all employees. Banks have realized that managing customer relationships is a very important factor in their success as Customer Relationship Management (CRM) is a strategy that can help them build long-lasting relationships with their customers and increase their profits through efficient management systems and the application of customer-focused strategies (Maritan, 2001). CRM in the banking sector is of strategic importance for exceptional customer service is a major indicator for customer retention leading to high profitability (Roh, 2005). CRM provides enhanced opportunities to use data and information to both understand customers and create value. This requires a cross-functional integration of processes, people, operations, and marketing capabilities that is enabled through information, technology, and applications. Quality of work life, the emotional evaluation of the individual, which means that the person is aware how much emotions and feelings and how they control the screw (Yonggui, 2004). The remarkable thing is that the quality of work life and they can be taught skills are not innate quality of work life. The environment is constantly changing and the manager is a key element in guiding this situation, with a little care on the various companies realize the great managers make a big difference. Effective leaders are those who earn results in a certain time frame to be effective for the company and their work (Robbins, 95, 1374). The issue of quality of work life and their relationship with the customer relationship management of critical issues in today's organizations. Banks have traditionally placed a high value on customer relationships with both commercial and retail customers. This results from the fact that consumer loyalty to a bank or other financial institutions, historically evolved out of personal relationships with local financiers (Thomas \& Sullivan, 2005). Consumers can perceive no advantage, beyond location, convenience, for selecting one bank over another. For marketers to alter perceptions and create consumer preference, banks need to evaluate their customer management strategy so as to be capable of delivering consistent and cost-effective customer service, customer-aligned products and services, and enhance customer loyalty and long-term value. Consequently, the ability to maximize customer loyalty through close, positive and durable relationships are critical to retail banks' ability to grow their businesses. 


\section{Research Goals}

This study aims at identifying the relationship between quality of work life and customer relationship management in private and public Bank branches. To this, the following objectives are as follows, according to Walton theory.

1. Identify relationship awareness and customer relationship management in state Bank of Maragheh city.

2. Identify the relationship management and customer relationship management in The state Bank of Maragheh city.

3. Identify the relationship between social consciousness and customer relationship management in state Bank of Maragheh city.

4. Identify the relationship between relationship management and customer relationship in State Bank of Maragheh city.

And applied research objectives are:

1. Evaluate the quality of work life in state Bank of Maragheh city.

2. Evaluation of customer relationship management in state Bank of Maragheh city.

3. Proposals to improve customer relationship management with respect to the quality of working life and the study of it.

\section{Theoretical Framework}

This study examines the relationship between quality of work life and customer relationship management.

A) Walton theory:

According to Walton job satisfaction, quality of work life consisted of four dimensions is based, which include:

Self-awareness

Self-management

Social Awareness

Relationship Management

B) Organization theory: include:

According to customer relationship management, customer relationship management consists of five aspectes

1. Altruism

2. Duty

3. Virtue of citizenship

4. Generosity

5. Respect and honor

\section{Research Method}

To collect of data, two methods of library and field is used.

To develop and theoretical research, library and to collect data from the population using the questionnaire survey method used. To collect information from the sample and to test the hypotheses uses questionnaire. In this study, data collection tools were used: The questionnaire quality of working life: The questionnaire was prepared by Walton (1973). The questionnaire has 29 questions with a range of five options (very low, low, medium, high, very high), respectively, score 1, 2, 3, 4 and 5 of them is awarded. Walton (1973) reported the reliability of the test 0/88. The population consisted of managers of state banks constitute the province that consists of 100 employees. In this context, and based on the formula, a sample of over 79 people and a questionnaire to determine their numbers were prepared and distributed. As well as to select the sample of the population stratified random sampling method is used.

\section{Results and Findings}

The following description of the results of this study is as follows:

- The majority of respondents (76 percent) is male and (24 per cent) are women.

- The majority of respondents ( 95 percent) is married, and (5 percent) included singles.

- The majority of respondents (56/96 percent) is bachelor's degree. $25 / 31 \%$ of education at the graduate level and above, 10 patients (12/65\%) have an associate degree, and finally 5/06 percent of respondents have a 
high school diploma or low literate.

- The majority of respondents (44/3 percent) of respondents aged $26-35$ years, $43 \%$ aged 36 to 45 years, $7 / 5$ percent under 25 years and 2/53 percent have 46 to 55 years and above 55 years.

- $\quad$ The majority of respondents (44/3 percent) of respondents from six months to 15 years, 43 percent of 16 to 25 years, $7 / 5 \%$ less than 5 years of work experience and $2 / 53$ have more than 25 years of service.

\subsection{Testing hypotheses}

The main hypothesis: the relationship between quality of work life of employees with customer relationship management

To test this hypothesis necessary after editing on the statements of the relevant variables significantly Pearson test was used. The results suggested that the quality of work life of employees with customer relationship management is a significant correlation Maragheh city state bank, which achieved a significance level $(\mathrm{Sig}=0.000)$ less than $\mathrm{R}$ alpha $(\alpha=$ 0.05 ) is, so the overall result is that the quality of work life better, customer relationship management as well as stateowned banks to be studied further. The overall result is that the quality of work life is better, as customer relationship management in state-owned banks to be studied further. The linear correlation between two variables, namely both simultaneously increase or decrease the intensity of correlation between two variables at intermediate level $(r=0.369)$.

That means that the employees' quality of life is better, customer relationship databases Mdysryt studied the positive side was going.

\section{Discussion of Results}

According Sergey et al. (2001), quality of work life is defined as employees satisfaction with the diverse needs of the resource, activities and outcomes that result from participation in the work environment. Studies show that employees with high work life quality report higher levels of determining identity with the organization, job satisfaction, job performance and a lower level of job desertion and self-alienation. Employee satisfaction with the quality of work life is difficult that damage all organization employees, regardless of position or rank. Many models have been proposed for quality of work life that shows it has many factors; however, the use of Walton's model is more common. Walton defined the quality of work life in 8 factors, including a fair and adequate payment, secure and healthy working environment, extended human capabilities, integration and social cohesion in the work organization, provision of opportunities for continued growth and security, social involvement of work life, overall living space and law orientation in the work. Customer service and relationship management are crucial to attaining a sustainable competitive advantage in the marketplace. The motivation for companies to manage their customer relationships is to increase profitability by concentrating on the economically valuable customers while possibly "de-marketing" and discontinuing the business relationship with less valuable customers. A successful CRM system must involve all people, processes, and information technology associated with marketing, sales, and customer service. In this study, we used this model (Walton model) here. The aim of this study was to determine the relationship between quality of work life of employees of the state banks Maragheh city is. According to the results of the employee's perspective the quality of life of employees with customer relationship management is a significant and had direct. This means that whatever amount their quality of life is better, customer relationship management in state-owned banks Maragheh positive side sills. Subject quality of working life and its relationship with customer relationship management categories critical in organizations today. Finally, the customer relationship management has the capability to communications and decision-making required to provide constant and continuous, high quality and low cost to beneficiaries of the offer. As well as the sales force more time for sales and a surge increase the effectiveness of sales, response time and quality customer service to increase the marketing department allows issues and trends clients better understand the information. Customer relationship management as a new technology created by the combination of information technology, information systems and marketing are created can be organized in achieving their goals and enhance profitability help. Useful and appropriate strategies for client banks circuit. System CRM can help existing customers maintain and attract new clients are. In the banking system, our main focus has been, and in fact everything to seek the consent of attention and attract them. Client goals to strategy of managing customer relationships is realized.

\section{Suggestions}

New proposals for the review of processes and engineering processes to improve customer relationship management in state banks should be considered. Banks without good design and process logic can achieve their goals. Banks must 
study processes related to customer relationship management to achieve this need improvement and develop. Business process re-engineering, is one of the most effective tools in this section. To managers about aspects of customer relationship management with a focus on human resource management to support systems thinking to be more aware. The staff should of interaction and contact with customers, specialized courses and practical training so that they can effectively communicate with clients and have the ability to use new technologies. Similar studies in other communities and provinces to perform research and compare the result with the study.

\section{References}

Andrade, S. (2003). Using Customer Relationship Management Strategies ,Applied Clinical Trials,Vol., 37, pp.37-41.

Johnson MD, Selnes F (2004) Customer Portfolio management: Toward a dynamic theory of exchange relationships. J. Marketing, 68:117.

Knox S, Maklan S, Payne A, Peppard J, Ryals L (2003) Customer relationship management: Perspectives from the marketplace. Burlington, MA: Butterworth-Heinemann.

Ling, R. \& Yen, D. C. (2001). Customer relationship management: An Analaysis Framework And Implementation Strategies. Journal of computer Information systems, 41(3), pp.81-97.

Maritan, C. A. (2001). Capital investments as investing in organizational capabilities: An empirically grounded process model. Academy of Management Journal, 44(3), pp.513-531.

Roh, T. H., Ahn, C. K. \& Han, I.(2005). The priority factor model for customer relationship management system success. Expert Systems With Application, Vol.28, pp.641-654.

Stone, M., Foss, B(2001). CRM in financing services: A practical guide to marking customer relationship management to work. London, Kong page.

Thomas JS, Sullivan UY (2005) Managing Marketing Communications with Multichannel Customers, J. Marketing, 69:239-251.

Vorhies DW, Hunt AM (2005) Benchmarking marketing capabilities for sustainable competitive advantage. J. Marketing, 69:80-94.

Yonggui, W., Hing, Po.Lo., Renyong, C., and yongheng, Y. (2004): An integrated framework for customer value and customer relationship-management performance, Managing Service Quality, Vol.14 No2/3. 